\title{
PROLOGUE
}

\section{GIACINTO GIGLI, CHRONICLER, OR: POWER IN THE STREETS OF ROME}

\section{Introduction}

High culture, low culture - elite and populace. Such constructed opposites have haunted the pages of cultural history for the past decades, and although the more sophisticated practitioners of the genre already seem to have abandoned them for a more integralist stance, the dichotomy still dominates the imagination. The study of Roman culture seems especially characterized by this divisive image: the refined civilization of the papal court, manifest in the grandiose monuments of the arts, of literature and of music - the culture of a group who cannot have numbered more than a few thousand people, mostly menat times seems a completely different world from the life of the other 90.00o or so Romans who made up the capital of the Papal States and of Catholic Christendom in a normal year.

But do we actually now how an 'ordinary' Roman, who did not really belong to this upper class, looked upon 'The Town', his town? The title of this Prologue shows I work from the assumption that whoever chronicled life in papal Rome would be primarily preoccupied with power. Indeed, after a first glance at the available material, I felt that such persons were indeed so inclined: most of the sources that fall in the category of texts chronicling the Town's daily life seem to record the many visible manifestations of power: power temporal, power spiritual and, of course, power supernatural. They concern the rituals of a capital that was excessively attuned to the outward manifestations of the complex power system that, within the theatre that was Rome, centred around the pope, his family and all the other persons and institutions that, together, embodied the Church which was the vessel of those powers. Obviously, however, such an assumption needs to be verified.

Of course, the opinions contemporaries formed and voiced about Rome could either be (self-)censored, with a view of spreading them among a wider public, or rather more candid, if they were recorded 
in private notes, only. Ideally, one should compare the two visions of Rome, starting, perhaps, with a study of the former. These, however, are represented in a source that cannot by analysed by a single researcher. I am referring, of course, to the information contained in the periodical mailings of the so-called avvisatori. It was these 'reporters', journalists avant la lettre who, to a large extent, determined the image that was created in the mind of a general, mostly non-Roman readership; they addressed a specific, though actually undeterminable audience, made up of foreign princes and of the officials who read their reports and, perhaps, summarised them - as the reports that came to Rome from all over the world were summarised by the Curia's clerks for the benefit of such persons as the Cardinal-Padrone. Yet, the readership of the avvisi that were dispatched from Rome - mostly once a week, and offering a selection of shorter or longer analyses or simply enumerations of what had happened in Rome in the previous daysmust have been rather wider than this small group; inevitably, in this day and age anything resembling a letter bringing news of foreign parts - especially of such foreign parts as the papal capital, the capital of the Church - was eagerly awaited by a wide circle of 'subsidiary' readers or rather listeners who hoped to be told the latest by the formal recipients of the avoisi.

The avvisi are among the sources historians use most for their reconstruction of life in Renaissance and Baroque Rome. They also are among the least studied. For though everyone ransacks these reports for the telling detail, for the one missing piece of information on a person or an occurrence no one ever seems to have asked what was the essence of the image of the Eternal City this stream of reports must have projected on those who relied upon them for their information, those who, avidly or reluctantly, read them as they arrived, week after week, in Florence or Venice, in Paris or Madrid. It seems strange that, as yet, no monograph ever has tried to analyse the verbal picture which the avvisatori painted of the Rome they were supposed to 'cover', being, in fact, what foreign correspondents are to the readers of today's newspapers. Yet, however desirable such a survey would be, even for the purpose of this modest Prologue an analysis of the avvisi covering Urban's entire pontificate would be well nigh impossible. A rough estimate indicates one would have to read some 16.000 folio sides, and itemize some i6o.0oo entries.

Therefore, this Prologue proposes to analyse a different text, written by one who definitely did not envisage its publication: it contains the 
notes made by Giacinto Gigli between the years i608 and I670; in regularly adding to his 'diary', he effectively created a chronicle of $\mathrm{I} 7 \mathrm{th}$ century Rome. Strangely, Gigli's diary has not been the object of a systematic analysis, either, although, again, it has been plundered by historians of the period ever since the beginning of the igth century. ${ }^{1}$

\section{The chronicler of Baroque Rome}

Giacinto Gigli was born in Rome on November, 23, I594 and died at the ripe age of 77 in December ${ }_{1671}$, having spent all his life in the same ward, the "Rione della Pigna" - as so many of his fellow Romans must have lived their lives within the confines of a small part of this big town, only. But though, perhaps, they did not even get to know the great extent of the city itself-large tracts of it were uninhabited, and, certainly at night, very dangerous - , they almost certainly would never leave the town's protective walls. However, Gigli did, for his family, of definite middle class origins, ${ }^{2}$ owned some land just outside Porta S. Giovanni, ${ }^{3}$ as well as a number of houses in various parts of town.

Gigli went to school with the Jesuits and, in I6r6, obtained a degree both in Roman and in Canon law. Obviously, he was a man of means, for he does not seem to have practised the law or, indeed, ever to have worked for his bread in any other capacity. He took care of the family interests, and fulfilled public functions on the intermediate level of the town's government. In January i631, Gigli was appointed to a three

\footnotetext{
${ }^{1}$ An exception must be made, however, for Barberito, who published the diary's most recent edition: M. Barberito, ed., Giacinto Gigli, Diario di Roma, I-II (Rome I994). To be quoted as: Gigli, Diario. In his introduction, Barberito does provide a somewhat thematic, though rather impressionistic and, strangely, judgemental analysis of the diary's contents. However, I feel he fails to see the main issues underlying Gigli's views. Barberito's edition certainly is to be preferred to G. Ricciotti, Giacinto Gigli, Diario (Rome 1957), although Barberito's notes are so copious as to be, almost, more of a burden than a help. Gigli’s life has been described by: A. Ademollo, Giacinto Gigli e $i$ suoi diarii del secolo XVII (Florence I877), which tries to make Gigli into a veritable anti-papal, anti-clerical chronicler. While this is a definite exaggeration, Barberito's claim that Gigli writes as a true historian, "sine ira et studio", is equally exaggerated. The only historian who used the diary's 'power slant' to good effect, incorporating some of the data provided by it in an admirable study of politics in Baroque Rome, is: L. Nussdorfer, Civic Politics in the Rome of Urban VIII (Princeton I992).

${ }^{2}$ Here, I disagree with Barberito, as he terms Gigli a member of the "piccola borghesia", though later he retracts this statement: Gigli, Diario, o.c., lxv and vii.

${ }^{3}$ Gigli, Diario, o.c., 769 .
} 
months' term of office as wardmaster, ${ }^{4}$ a function which he was to hold six more times during the following decades. In April, I638, he became "Priore di Roma", i.e. head of the 'College of Wardmasters' for what was to be the first of three times. ${ }^{5}$ Such positions must have given him a rather more privileged view of Roman life than the man in the street would have had. They also may explain why his diary is, often, wellinformed indeed. For, at least at first sight, it seems Gigli was of the stuff chroniclers are made of, jotting down notes of an autobiographical character from an early age, and, from i608 onwards, also keeping a diary of sorts. From i6rg, the year of his marriage, onwards, the diary gets all his attention, though he was not always able to sit down and bring it up to date. Apparently, he experienced this as failing in his duty for when, during the first months of the Holy Year i625 he was ill, he excused himself on paper for not having been able to properly describe this special year, expressing the hope, however, that he might live to see another one. ${ }^{6}$ The fact that his notebook was important to Gigli also appears from the care that - despite the occasional slip of the pen, as when he forgets to give a sentence its subject ${ }^{7}$ - he bestowed on his manuscript. Sometimes he even assumed a fictive reader whom he directed from one note to another, as, e.g., in December i624, when he records the "damnatio memorii" of that famous heretic, the former Jesuit Marc-Antonio de'Dominis, the also former archbishop of Spalato - modern-day Split-, turning his 'reader' to a note made in 1617 , where this prelate's papal aspirations had been mentioned. ${ }^{8}$ Indeed, Gigli definitely must have gone through his notes at regular times, inserting cross-references linking what happened to earlier or later occurrences. ${ }^{9}$

Bearing all this in mind, the 'diary of Giacinto Gigli' yet does present some problems. First of all, terming Gigli's text a diary calls to mind the detailed descriptions that make the far more famous diaries kept by men like John Evelyn and Samuel Pepys such a delightful read. If one were to open the Diario with such examples in mind, one would be sorely disappointed. Mostly, Gigli records one or two items a month.

\footnotetext{
4 Gigli, Diario, o.c., 205.

5 Gigli, Diario, o.c., 307.

6 Gigli, Diario, o.c., I40.

7 Gigli, Diario, o.c., 331, May I640.

8 Gigli, Diario, o.c., I39 and 58.

9 E.g. Gigli, Diario, o.c., 255; 266; 268; 283.
} 
Sometimes, many months pass without even a single remark. This, obviously, poses the question of his selection criteria. It seems unanswerable. For even the following analysis has left me asking what really moved him to note the things which, in fact, he did note, knowing, as one does, for example from a cursory reading of the avvisi, that at the same time so many other things were happening in Rome that must have caught a shrewd observer's attention. The fact that Gigli really meant to keep a private diary, apparently not intending it ever would be used to inform and thus affect an audience, is of no great help, either. For while one would assume this stance must have influenced both his choice of what to record and of its presentation, there still seems no rational link between the private, effectively 'anonymous' nature of the text and its contents which are not nearly as outspoken as, for example, the equally anonymous "Pasquinate", the notes affixed to the statue of an ancient god that publicly and often vehemently voiced popular opinions in the papal capital - though, sometimes, these very notes may have been used by papal officials to uncover anti-governmental feelings among the population.

Notwithstanding these limitations, within the context of the questions raised in this book, Gigli's diary yet is a precious source indeed, as I hope to show through my reading of that part of it which covers the pontificate of Pope Urban VIII, which I have structured around seven major and, to my opinion, central themes.

\section{The powers of nature}

Obviously, in a town and a time wherein food supplies were of central concern to all but the most wealthy, the years when harvests were good and grain was abundant are mentioned by Gigli, ${ }^{10}$ and so are the moments when, for whatever reasons, the harvest fails, as in May I634, when a hail storm almost totally destroys it and the price of bread doubles immediately, ${ }^{11}$ or in the early months of 1637 , when tempestuous rains batter the fields. ${ }^{12}$ Whereas in an earlier age, a Christian chronicler might have attributed the vagaries of nature to a higher power, interpreting the bad spells as signs of God's wrath, Gigli does not seem

\footnotetext{
10 Gigli, Diario, o.c., 236.

11 Gigli, Diario, o.c., 250; 282/283.

12 Gigli, Diario, o.c., 289.
} 
to have looked upon the world in that way. He does mention the severe draughts that reigned from July to November I635, and the ensuing deaths are recorded as well, but he seems to accept that the daily prayers said during mass were to no avail. ${ }^{13}$ Yet, such a story as the one of the showers of grain that decked the earth all around Vienna in spring I630 seems to him entirely trustworthy, precisely because proof of it, in the form of the grain itself, is brought to Rome. ${ }^{14}$

The annual inundations of the Tiber get no more than a passing reference; obviously, they were part and parcel of the cycle of Roman life, as were the many fires that regularly occurred. ${ }^{15}$ But such spells of extreme cold weather as the one of February, I627, or, again, of November, I640, which caused many people to die of a feverish catarrh - mostly the elderly, as well as women living in monasteries and children - were worthy of mention. ${ }^{16}$ When a house suddenly caved in, and many people died under the debris, Gigli relates the circumstances in considerable detail; indeed, the numerous accidents of this kind always get a note in his diary. ${ }^{17}$

However, looming largest in Gigli's tales are the threats posed by the plague that recurs almost annually. In August, i6zo, the tale is particularly gruesome because rumour has it that the warring parties in northern Italy, led by the imperial troops, have started using a poison made of a certain evil substance that can induce the illness, which now is being spread by a criminal band of men who tour the country, even mixing it with the holy water people use to sprinkle themselves with in church. In Rome, too, panic reigns. The Pope, disregarding normal practice, orders the clergy to have priests suspected of this heinous crime to be tried and condemned by secular courts. ${ }^{18}$

Within the same context, Gigli always mentions the prayers and processions ordered by the Pope to ward off the danger of the plague, implying that in this respect, at least, the presence of a monarch who combines the temporal with the spiritual power is beneficial to Rome. ${ }^{19}$ On such occasions, no fewer than 40.000 people - i.e. nearly half the population - might gather together; Gigli, obviously moved himself,

\footnotetext{
13 Gigli, Diario, o.c., 27 I.

14 Gigli, Diario, o.c., I9I.

15 E.g. Gigli, Diario, o.c., 2 I2, and passim; 313, and passim.

16 Gigli, Diario, o.c., I65; 304; 334 .

17 Gigli, Diario, o.c., I50; 297.

18 Gigli, Diario, o.c., I97.

19 E.g. Gigli, Diario, o.c., I93; I95.
} 
tells how the spectators, touched by the devotion of those participating in the procession and ashamed to be looking on in silence, only, start joining in as well. ${ }^{20}$ When, in 1632 , it seems that Rome has been spared, whereas so many other Italian towns have been devastated, he fully enters into the spirit of the festive Te Deum that is sung in Sta Maria in Aracoeli, the Town's 'civic' church near to the Capitoline Hill. ${ }^{21}$ He describes the five hour-long procession made up of everyone who matters in the city that, in March, carries a precious banner from St Peter's to be hung in Sta Maria Maggiore in perpetual memory of the Roman people's gratitude; flanking an image of the Madonna between Sts Peter and Paul painted by Pietro da Cortona - one of the few times Gigli actually mentions an artist - it shows the papal arms, surrounded by the Barberini bees, and the coat-of-arms of the Roman People.22 Gigli notes that just like Saint Gregory, carrying the image of the Madonna in procession around town, had obtained that Rome was liberated from the Plague, so Pope Urban, who (granting the jubilee for this cause) almost every Sunday went to Saint Mary Major to say mass, by means of that Image received God's grace'. ${ }^{23}$

Yet, Gigli was ill-satisfied with the manner in which the thing had been organised. At the head of the procession had walked the 'common people', instead of as many noblemen and other persons of consequence as could have been mustered, and, of course, the city officials themselves; for why had they been forced to buy, at their own expense, sumptuous clothes et cetera, if not to shine on such occasions and show Rome's glory? While this observation, of course, represented Gigli's view of the world rather than of nature, it did so precisely in a situation wherein that world reacted to the forces of nature.

\section{The powers of the world}

Gigli's view of the world outside Rome - the world of Italy, of transalpine Europe and, of course, of the Mediterranean - was limited. Not, one must assume, through lack of information - for Rome, of course, was one of the best-informed towns of Europe and, indeed, of the

\footnotetext{
20 Gigli, Diario, o.c., I94.

1 Gigli, Diario, o.c., 220.

22 Gigli, Diario, o.c., 220/222.

23 Gigli, Diario, o.c., 222.
} 
world, with news quickly spreading from the offices of the Curia to the streets outside - but supposedly because he simply was not interested. Thus, such a major event as the Peace of Westphalia, in I648 - to take an example from the pontificate of Innocent $\mathrm{X}$-is not mentioned, which is, actually, surprising because it ended decades of war that also had ravaged the Italian peninsula and had indeed caught Gigli's attention on several earlier occasions.

Yet it seems Gigli perceived international politics and the play of power only insofar as they directly affected Rome itself, or the policies of the Church. Thus, he became aware of the threats posed by the Ottoman Turks, which were increasingly felt during the late i6zos, perhaps only because these induced Pope Urban to order the entire clergy to participate in a number of large-scale processions. ${ }^{24}$

It seems evident Gigli did not harbour any great illusions about the political power of the Pope in the temporal affairs of Europe. When Urban's nephew, Cardinal Francesco Barberini returned from his long peace-negotiating mission to France, Gigli dryly notes that he 'has accomplished nothing. ${ }^{25}$ When Francesco departs for, and returns from Spain on a like errand, Gigli feels he has not been able to make any headway, either. ${ }^{26}$

The 'big world' entered Gigli's vision also whenever a new Catholic prince ascended the throne, or when an heir was borne to one of them or, equally important, when they obtained a victory in the wars that continually were waged during these decades - for then the Pope and the Sacred College would show themselves in the streets of Rome to assist at a celebratory Te Deum in an appropriate church. ${ }^{27}$

In short, Gigli looks at things mostly from a Roman point of view. When problems arise between Urban and Venice, and the Most Serene Republic recalls its ambassador, he refers to the end of the squabble with a note saying that 'the Venetians were returned to the Pope's grace in the year I639 and once more sent an ambassador to Rome'. ${ }^{28}$ The death of Cardinal Richelieu is mentioned because he was supposed to be the evil genius who had instigated the Duke of Parma to rebel against the Pope. His successor as the French king's chief adviser

${ }^{24}$ Gigli, Diario, o.c., 317/318.

25 Gigli, Diario, o.c., I44.

${ }^{26}$ Gigli, Diario, o.c., I58.

${ }^{27}$ E.g. Gigli, Diario, o.c., I99; 223; 225; 289; 313, et cetera.

${ }^{28}$ Gigli, Diario, o.c., 282. 
is recorded because, of course, he was a Roman - Giulio Mazzarini. ${ }^{29}$ In I643, the French royal couple, Louis XIII and Anne of Austria, went out of their way to thank God for the birth of an heir, donating an ensemble of solid silver statues, including the Madonna and a likeness of the new Dauphin to the shrine at Loreto; Gigli only seems to mention it because on its way to the famous sanctuary it was accompanied by a present for the Pope, consisting of books including an edition of the Pope's poems, but bound in such a costly way that their value even exceeded that of the gift to the Holy House. ${ }^{30}$ Finally, it seems Gigli only records the revolution in Portugal, in i640, because when the new king decided to send a high-ranking prelate as his ambassador to Rome, the Spanish government protested against this man being received by the Pope. Urban, however, as was his wont in the tangle of international politics, immediately declared himself the "Padre comune de" Christiani" and allowed the ambassador to enter town and be received by Cardinal Barberini. ${ }^{31}$ Alas, the poor Portuguese soon became the centre of locally-fought international intrigues as a pawn between the French and the Spanish factions in Rome. In August I642, things came to such a head that many people died in various kinds of armed incidents. When the Archbishop of Lamego departed, the French ambassador, angry at the way the papal authorities handled the conflict, left as well..$^{32}$

Obviously, to Gigli power, and especially politics seemed a sordid game, often associated with devious and secretive dealings and fraught with many dangers. Thus, he knows papal representatives abroad are far from immune to the perils of power; indeed, the papal nuncios are constantly at risk of being poisoned. ${ }^{33}$ But at home, too, life is anything but safe for those who are in power, or are connected with the power game, as appears from the complicated story of the double-dealing robber baron Giulio Pezzola, who heads a band of thirty bandits and, entering the Papal States from the Spanish Regno, the Kingdom of Naples, makes life miserable for the Pope's people. Cardinal Barberini finally decides to 'hire' this man's services, in order to have someone who knows how to combat the banditry that is rampant within the Pat-

\footnotetext{
29 Gigli, Diario, o.c., 373.

30 Gigli, Diario, o.c., 387 .

31 Gigli, Diario, o.c., 355/356.

32 Gigli, Diario, o.c., 358/360; 372/373.

3 Gigli, Diario, o.c., e.g. I89.
} 
rimonium itself. Yet, the Cardinal soon finds himself implicated in a case of double-dealing, for Pezzola also appears to be mixed up in the secret conspiracies of a Neapolitan nobleman against the Spanish government; to make matters even more complex, the robber soon betrays this latter gentleman to the Spanish viceroy who, finally, has him killed. ${ }^{34}$ With the French, always fishing in politically troubled waters implicated as well, the entire episode turned into a major diplomatic incident, causing both the French and Spanish ambassadors to boycott the papal audiences for some time. Yet, Gigli obviously thought that Rome and the papacy were the offended party. ${ }^{35}$

Constantly people themselves involved in the power game, or only criticising those in power, were made to feel the dangers. That much became clear when, in I643, the Pope's private preacher, Father Albritio, S.J., was dismissed because he was suspected of having given a sermon alluding to a prince's need to heed his subjects, as the Pope should heed his unruly vassal, the rebelling Duke of Parma. ${ }^{36}$ On quite another plane, in the complex ceremonial battle surrounding Taddeo Barberini's elevation to the prefectorate of Rome, the coachman of the Venetian ambassador was threatened by the Barberini to halt his master's carriage in sign of respect; however, when he did indeed do so, he was forced to flee the Venetian embassy for the security of the Barberini-Colonna's castle of Paliano; subsequently, he was found murdered there. ${ }^{37}$ To cite yet another case, in 1638 , one of the Roman judges and his servant were seriously wounded by three ruffians, apparently men who felt they had an axe to grind with this official. $^{38}$

Yet, sometimes, Gigli seems to think that what befalls those who hold power serves them right. When, in April i639, Monsignore Pietro Colangelo dies of his own blood, which had risen to his throat and suffocated him - the entire room in which he died being flooded by it, too-Gigli gives vent to a mixture of feelings. It seems he considered this death a case of - divine, supernatural?-retribution, the consequence of the arrogance of power. ${ }^{39}$ For as 'Fiscal of the Campidoglio', which meant judicial representative of the Pope in town government,

\footnotetext{
34 Gigli, Diario, o.c., 330.

35 Gigli, Diario, o.c., 323/324.

36 Gigli, Diario, o.c., 402.

37 Gigli, Diario, o.c., 2 Iо.

38 Gigli, Diario, o.c., 307.

39 Gigli, Diario, o.c., 3 I8.
} 
Colangelo had usurped a number of privileges which by right should have remained within the hands of the city council. Typically, the man had acquired his position by playing up to the Pope and the Barberini family.

\section{The "Urbs" as a physical manifestation of power}

To Gigli, the entire city seems an archipelago, made up of islands of power: power temporal, with sometimes entire wards but, more often, squares and piazze dominated by the palaces of the Roman nobilitythere's a 'Piazza dei Signori Colonna', a 'Piazza dei Signori Farnesi', and now, of course, a 'Piazza dei Signori Barberini', as well- but also power spiritual, as in the case of the big churches and the adjoining monasteries, dominated by the various religious Orders: a 'Piazza dei Padri Gesuiti', et cetera.

Whenever there is an occasion to celebrate, both noblemen and religious corporations use their part of town, including the surrounding houses and apartment buildings, as a 'theatre'. ${ }^{40}$

Thus, during the ceremonies accompanying the formal declaration of the 26 martyrs who died for their efforts in spreading the faith in Japan and had already worked many miracles, the Jesuits, counting three of their Order among this number, organised a marvellous feast, decking the façades of the Gesù and the adjacent houses with coloured lights and exhibiting a big canvas by the famous painter Arpino showing their three martyrs. The Franciscans, who had contributed the other blood witnesses, had shown theirs in the church of Aracoeli. ${ }^{41}$

When, some years later, the Jesuits celebrated their centenary, not only did they illuminate all their buildings in Rome for a number of days, but so did 'many persons who bear them particular affection'. ${ }^{42}$ In the same year, they showed their trust in the power of propaganda by staging elaborate ceremonies during which portraits were exhibited of those who, among the Christian world's spiritual and temporal princes, had been their benefactors. Gigli was quick to note that although this feast was meant to honour the dead, symbolised in the Gesù being

\footnotetext{
40 E.g. Gigli, Diario, o.c., I47, I7I.

41 Gigli, Diario, o.c., I66; I70/ I7ı.

42 Gigli, Diario, o.c., 32 I.
} 
entirely decked in black, the church's white marble pilasters were left in view, which, strangely, produced a 'cheerful effect'. ${ }^{43}$

The Jesuits seem to have been specifically adept at making their presence felt. In August, I640, Gigli recorded the celebration of the feast of St. Ignatius, which once more turned out to be a show of the Order's power, this time not only by a public exhibition of the portraits of all cardinals who had ever studied at the Collegio Romano, including the three Barberini ones, but also by a display of the likenesses of all the published scholars they had produced, and as well as of pictures of the numerous towns all over the world where the Order had an house. ${ }^{44}$

Then, of course, there are those parts of papal Rome which are dominated by a 'foreign' nation, either because that is where their embassy is - thus, e.g., the area around the Palazzo Farnese after it had been sold to the French government-, or because it is a part of town inhabited by a considerable number of families who had migrated to 'the City' from other Italian city-states. Among them, the Florentines are most conspicuous. They, too, like to manifest their power when occasion arises..$^{45}$ Sometimes, in order to do so, they join forces with powerful families, whose protection or favour they need. The Florentine 'nation', for example, was heavily involved in trade and finance, and therefore needed to curry favour with the powers-that-be.

Inevitably, families who boast a saint among their members come in for Gigli's special mention. Thus, he tells of the Corsini with 'their' Sant'Andrea; the family paid handsomely for ceremonies celebrating the sanctification of their holy relative. Moreover, since they belong to a 'foreign' nation - in this case the Florentine one, again - the entire group showed its pride in staging grand festivities, using the occasion to also display the likenesses of all the other Florentines who had been either beatified or raised to the honours of the altar; for good measure, they threw in the portraits of the five Florentines who had been popes, as well as the coats-of-arm of the sixty cardinals produced by their native town over the centuries. ${ }^{46}$

The Sacred College looms large over the picture Gigli paints of papal Rome. He seems to hold its members in some traditional reverence

43 Gigli, Diario, o.c., 323.

44 Gigli, Diario, o.c., 332/333.

45 Gigli, Diario, o.c., I33.

46 Gigli, Diario, o.c., I77/I78. 
though he knows them to be the favourites either of the reigning pope himself - i.e. his relatives and, as when the Barberini allied themselves with the Colonna, some of their in-laws as well ${ }^{47}$ - , or of the secular princes of Europe. ${ }^{48}$ The fact that few men made it to the cardinalate on their own steam is obvious if only because Gigli, whenever a cardinal dies, never fails to mention whose 'creature' he was. Indeed, it seems unlikely Gigli had a really high opinion of the Princes of the Church. He knew that one could buy one's way into the Sacred College, as, for example, the Genoese banker Lomellini did, who purchased the position of treasurer of the Apostolic Chamber for 80.000 scudi knowing that if or rather when the Pope needed some ready money, he would make him a cardinal, which would force him to resign this office that, then, could be put up for sale by the Camera Apostolica once more. Gigli is having a quiet laugh when, soon after, Lomellini dies. ${ }^{49}$ Some men, however, did succeed this way, as, e.g., Francesco Rapacciolo, the son of a wealthy Roman draper, who used his family's money to acquire the same office and then became a cardinal in $1643 .{ }^{50}$

Though Gigli, as so many in his time, did believe in the natural, hierarchical order of society, thinking that whatever the ways one reached the cardinalate, a cardinal at least should be of noble birth, he forgave his Eminence Pignatelli his 'base lineage' because being 'dextrous in affairs' obviously made up for it. ${ }^{51}$ Nor did he fail to mention that Cardinal Rondinini was the son of a mother who was the natural, i.e. illegitimate daughter of Cardinal Zacchia. When Giovanni Giacomo Panzirolo became a cardinal, he the offspring of a Roman dress maker, Gigli described him as a man with 'nice manners, a noble way of dealing with people, and possessing the art of making himself thought well of'; thus, he had become the friend and confidant of Cardinal Barberini, rose to be papal nuncio in Spain, and then entered the Sacred College. ${ }^{52}$

The cardinals were manifestly present in Rome's townscape, with their "antica pompa" which shows in numerous big and small ways, if only in the carriages and litters in which they even were allowed to enter the churches. From i625 onwards, such elements of visual

\footnotetext{
47 Gigli, Diario, o.c., I7I.

48 Gigli, Diario, o.c., I58.

49 Gigli, Diario, o.c., 388/389.

50 Gigli, Diario, o.c., 396.

1 Gigli, Diario, o.c., I3 I.

2 Gigli, Diario, o.c., 395/396.
} 
presence were enhanced when it was decided that their carriage horses were to carry red plumes. ${ }^{53}$ But the greater change came in i63o, when the Pope ordered that the cardinals from now on be addressed as 'Eminencies', instead of being named 'Illustrious', a mode of address now so common as to denote next to nothing. Up till then, only the seven prince-electors of the Empire, and the Knight Grand Master of the Order of St John had been styled 'Your Eminency'!

Gigli was not much given to musing on the fine arts and their products in Rome, unless, perhaps, those that seemed to particularly celebrate its status as 'The City'. The names of the architects, painters and sculptors who created and decorated the physical city in which he lived and whose many new buildings he must have seen rising around him - such as the huge mass of the new Palazzo Barberini-are conspicuously absent from his diary, excepting a few rather unexplainable instances. Nor does he always mention the occasions when papal policy regarding the ancient monuments added lustre to the town's almost mythical antiquity. Yet, an explanation for the fact that the death of two antiquaries comes in for a short note,$^{55}$ might be found precisely in his obvious civic pride for, with their knowledge, they had contributed to the fame of Rome as the Eternal City. Such an explanation might also hold for Gigli's rather extensive description of the excavation of the triumphal arch of the Emperor Claudius, ordered by Cardinal Barberini in I64I, at which, moreover, as Prior of Rome, he was present himself, even descending into the digs to have a candle-lit look at the sculptures and take home some pieces of yellow marble. ${ }^{56}$ Also, he does recount that the Pope decided to have the name of Alexander the Great removed from the two huge marble statues on Monte Cavallo because scholars had told him that, if these statues were indeed the fifth-century works of Phidias and Praxiteles, respectively, they could not very well represent a man who had lived two centuries later. Yet, Gigli does not explain the Pope's action that, anyhow, should have followed the other option, as the statues do, after all, bear Alexander's face. ${ }^{57}$ Perhaps the Pope reasoned he would rather have the works of famous sculptors

\footnotetext{
53 Gigli, Diario, o.c., I52.

54 Gigli, Diario, o.c., I93.

55 Gigli, Diary, o.c., 298.

56 Gigli, Diario, o.c., 346.

57 Gigli, Diario, o.c., 25I. Cfr. C. d'Onofrio, Un popolo di statue racconta (Rome I990).
} 
adorn his capital than the likeness of a man whom only some of his predecessors had chosen as an example and namesake - and they not the most holy ones. Gigli probably would have agreed.

He certainly voiced his opinion more openly when Urban ordered that the bronze fittings be taken from the architraves of the Pantheon, as the papal foundries needed the metal to forge canon. Gigli described and obviously fell in with the dismay of the Roman populace that 'such a beautiful Antiquity, the only thing to have remained intact from the plundering of the barbarians, and, indeed, a work that could truly be said to be eternal' was now being dismantled. When it was found that the bronze was mixed with silver and gold and, therefore, unfit for its proposed use, the Pope hastily decided to stop ruining the building and ordered the architraves to be covered again. ${ }^{58}$ To this passage Gigli added information which came from the year 1632 when the Pope chose to commemorate the fact that, besides for the guns that had been founded, he had taken the bronze to be fashioned into the four huge columns that supported Bernini's baldachin over St Peter's tomb, with two huge inscriptions that now were attached to the ancient monument; Gigli approvingly cites the texts in their entirety..$^{59}$

As to the modern embellishment of the town, a near-complete silence reigns in Gigli's diary. Thus it remains unclear why, of all possible artists he could have mentioned, he selected for the record the sculptor Francesco Mochi whose huge statue of Veronica in 1640 was put up in its niche in one of the four pillars carrying Michelangelo's grand cupola of St. Peter's. ${ }^{60}$ The absence of references to cultural manifestations stricto sensu is even stranger in view of the fact that Gigli was something of an erudite, who wrote poetry and dabbled in philosophy and archaeology. ${ }^{61}$ Mentioning the unhappy episode of Bernini's bell tower for St Peter's, which collapsed because of unsound construction, seems occasioned only by the Cavaliere's discomfiture that caused him to fall ill and, so rumour had it, nearly to die. ${ }^{62}$ As to the rebuilding of the Fontana di Trevi, in I643, which entailed both its reorientation and its decoration with, of course, the Barberini bees, it may have been mentioned only as a case of concealed criticism, because Gigli added

\footnotetext{
58 Gigli, Diario, o.c., I54.

59 Gigli, Diario, o.c., I54.

60 Gigli, Diario, o.c., 334.

61 Ademollo, o.c., 9-I I.

62 Gigli, Diario, o.c., 34I.
} 
that it all was done because the Pope wanted to be able to see the fountain from his summer residence on the Quirinal Hill. ${ }^{63}$

The only exception to what almost seems to have been Gigli's rule occurred in November I626, when the consecration of new St Peter's elicited a longish description of the history of the second Petrine basilica, and of Urban's finishing touch, the altar and its bronze columns, as well as of the solemn procession which wound through Rome from Piazza Venezia to St Peter's and continued all around the new church. ${ }^{64}$

Yet, despite his seeming lack of interest - at least in his diary notes in the city's growing physical splendour, Rome, to Gigli, is an object of immense pride that cannot but lure foreigners to come and see its many glories and great power, whether they hail from Europe or from farther climes, as in the case of the 'nephew of Prester John' who arrived from Asia with a delegation of Franciscan friars. ${ }^{65}$ That people should bring strange things to it to him seems only natural, as when, a century after the first time they ever saw an elephant, the Romans once more could go and gaze at such a strange beast. ${ }^{66}$

Understandably, Gigli is afraid for his town's fate, especially when the wars in northern Italy escalate. It is then that the traumatic memory of the infamous Sack of Rome, which had occurred a century earlier, surfaces again, in a description of the horrendous cruelties now perpetrated by the present emperor's German soldiers who, being the heretics they are, once more are bent on devastating Italy and damaging the Church. They violate the 'sacred virgins', desecrate the churches and use the holy oil to wax their boots and, sacrilege if ever there was, affix the host as a seal to their letters. ${ }^{67}$ Rome, inevitably, is made to feel the consequences of this threat. Prices rise, the quality of the bread deteriorates, and each day brings new taxes. People grumble, ${ }^{68}$ and, of course, their grumbling is directed at the powers-that-be.

\footnotetext{
63 Gigli, Diario, o.c., 395.

64 Gigli, Diario, o.c., I60/ I6I.

65 E.g. Gigli, Diario, o.c., I7ı; 23І.

66 Gigli, Diario, o.c., I9I.

67 Gigli, Diario, o.c., I8I.

68 Gigli, Diario, o.c., I8I; 205; 21 I, 212, et cetera.
} 


\section{Papal power}

In many ways, Gigli was a cynic, who held few illusions about the papacy or the people's views of it. When Pope Gregory XV died in July, I623, Gigli looked back upon his pontificate and noted how many unrealistic hopes the Roman people had invested in the Bolognese cardinal, longing for someone and something new after the nearly sixteen years Paul V had sat on St Peter's throne. Soon, however, they realized the good things they had hoped for would not materialize, while the bad remained, with the public debt increasing alarmingly and even the sacred papal treasure chest, in its vault in Castel St Angelo showing its bare boards. Of course, as always people had not blamed the pontiff himself but his nephew, in this case Cardinal Ludovico Ludovisi; however, Gigli seems to imply that this is a rather silly attitude. ${ }^{69}$

As to the mechanism that finally produced a new pope during the I623-conclave in which 6o- of the maximum number of 70 - cardinals participated, Gigli had no illusions, either. If he privately believed the Holy Spirit entered into the process at all, he concealed such an emotion even to his diary, in which he openly declared it was all a power game in which, in this case, the former Cardinal-Padrone Scipione Borghese, the nephew of the late Paul V, and his faction set out to have one of their allegiance elected,$^{70}$ obviously to ensure the continuance of their own power. Gigli, as well as the conclavisti themselves, felt that evil but evidently this-worldly forces were at work: both Cardinal Barberini and others let it be known they thought they had been slowly poisoned - with Maffeo maintaining that a bunch of flowers had been used to do so. ${ }^{71}$ Yet, despite the fact that any mention of Heavenly interference is lacking, Gigli strangely seems to be of two minds about the famous story telling that before Cardinal Barberini was finally chosen by the ballot, a flight of bees had been seen to alight above the cubicle where he slept, forming itself into a papal tiara. ${ }^{72}$

Obviously, whatever Gigli's personal feelings about Urban, the fact that the Pope was the supreme power made anything that happened

\footnotetext{
69 Gigli, Diario, o.c., I20-I2 I.

${ }^{0}$ Gigli, Diario, o.c., I 22-I24.

1 Gigli, Diario, o.c., I3I, I32.

72 Gigli, Diario, o.c., I25.
} 
to him important news. Thus, when Urban nearly collapsed during mass, the information was added to the diary. ${ }^{73}$ When he fell seriously ill in April 1637 that was recorded, too, as were the other ailments that from then on continued to plague him. ${ }^{74}$ Implicitly, perhaps, Gigli was expressing his fear that the Pope might die. True, this would bring a Sede vacante and thus a period during which the town would rule itself, as of old. But Gigli was realistic enough to know that without the restraints of papal power, it would be chaos that ruled, rather than he and his fellow town-officials. ${ }^{75}$ Indeed, when the Pope recovered, almost everybody was overjoyed, and the French ambassador ordered a display of fireworks, while the 'People of Rome' had a Te Deum sung at Sta Maria in Aracoeli, and grain was dispensed for free. ${ }^{76}$ Not everyone was happy, though. Cardinal Laudivio Zacchia, from Genoa, had held high hopes of being elected after Urban had died - and so had his relatives. Now the poor man died himself - of chagrin, it was said. $^{77}$

The Pope's power as a temporal ruler in his own state was keenly felt by the Romans if only because, as in the olden days, he or his representatives were the only ones who could keep a rein on the soldiers who, of course, one needed but dreaded as well. Thus, when the number of troops in Rome increased during the war with Parma in I64I, it took the authority and, so Gigli implies, courage of the acting Cardinal Camerlengo, Antonio Barberini, to stop the mercenaries from creating havoc. ${ }^{78}$

Papal power was manifest, too, when individual subjects, however powerful they thought themselves, failed to comply with the rules of the state. Thus, for example, the Duke of Ceri, resenting the way papal officials tried to manage the judicial affairs of his duchy and threatening them with guns, even wounding one of the policemen accompanying them, was imprisoned in Castel St Angelo and then banished to Avignon. ${ }^{79}$ Mario Frangipani, too, for all his family's power,

\footnotetext{
73 Gigli, Diario, o.c., 266.

74 E.g. Gigli, Diario, o.c., 307.

75 Gigli, Diario, o.c., 295.

76 Gigli, Diario, o.c., 297; 298.

77 Gigli, Diario, o.c., 298.

78 Gigli, Diario, o.c., 353; for subsequent cases: 354, 355.

79 Gigli, Diario, o.c., 330.
} 
was sent to prison when he murdered someone on his estates. ${ }^{80}$ Both were released only when their military capacities were needed in the war against Parma. ${ }^{81}$

Indeed, the Pope's power to punish evidently made much impact if we judge it by the frequency of the tales told by Gigli about crime and its consequences. Obviously, he felt that the presence of precisely such a power was of the greatest importance. This first appears from the descriptions he gives of the Sede vacante-periods, during which Rome and the Catholic part of Europe held their breath. Awaiting the outcome of the conclave, for the time being Rome was ruled again by its ancient, elected officials: Gigli's 'class' of people. But whatever he may have thought about the harshness of papal government, he well realized that without it the town lay prey to almost unrestricted violence. Thus, during the barely two weeks that passed between the death of Gregory XV and the election of Urban VIII, the city was racked by theft and murder, with many corpses simply left in the streets, or thrown into the Tiber, decapitated and otherwise mutilated. Policemen were molested, and one of the ward-masters was stabbed with a knife; as a matter of course, the unruly soldiers serving the foreign ambassadors, who even in regulated times only could be kept under guard with some difficulty, now took their freedom and ran riot. $^{82}$

However, crimes which almost daily occurred such as 'ordinary' murder came in for Gigli's attention, too, as when a young man strangled his older relative: his hand was cut off, in front of the house where he had committed his crime, and he was then decapitated and his head put on a pike on the piazza nearby. ${ }^{83}$ Some of the deaths Gigli records were bizarre indeed, having an almost Boccaccian ring to them. In one case, a noble nun who wanted her paramour help her get out of the monastery, had a frightful shock. The young man, thinking to be clever, had himself closed into a box that was to be delivered to her. As the servant who was to carry the box tarried in doing so, the man suffocated and was discovered dead when the nun opened her present. Finally, she had to confess all to the abbess, and the Pope ordered that

\footnotetext{
80 Gigli, Diario, o.c., 334.

1 Gigli, Diario, o.c., 364/365.

22 Gigli, Diario, o.c., I25.

83 Gigli, Diario, o.c., I79.
} 
she be immured alive. ${ }^{84}$ In another, complicated case, a girl was forced to marry a wealthy suitor whom she, secretly loving another, disliked intensely but who was preferred by her parents; it all ended in a rather farcical tragedy of disguise and mistaken identities in which she died, but Gigli notes the details at extraordinary length and with apparent relish. ${ }^{85}$ Equally revealing is the case of the female convert who murdered one nun and seriously wounded two others who had come out to see what caused the alarm. The Pope immediately ordered that she be strangulated in the monastery itself. When, before dying, she confessed, revealing, however, that she had acted on the orders of one of the principal nuns, a lady from the highest nobility, nay, a princess from the house of Aldobrandini-family who had risen to power and wealth through Pope Clement VIII - this woman was immediately imprisoned for further interrogation. Obviously, in view of the sensitivity of this case, it was dealt with in the greatest secrecy, but despite her high rank, this nun, too, was put to death in the monastery. Thus, it seemed, the Pope's power to punish was absolute, and nobody was spared. ${ }^{86}$

When a prelate decided to kill one of his creditors, and took refuge in a church, papal officials employed an undercover agent to lure him home on the pretext that he would be safe, there; subsequently, the man was jailed and sentenced to decapitation, probably also because his house was found to contain a number of "Pasquinate"-Gigli does not tell whether these were directed against the ruling powers, but this seems rather likely. Afterwards, the culprit's head was publicly exhibited ${ }^{87}$

As arson was a crime that regularly occurred but, apparently, left little proof, and thus no suspect who could be tried and punished, it only got a passing mention. ${ }^{88}$ When, however, conspiracies against the Pope's life were discovered, Gigli does not fail to describe them. ${ }^{89}$ Especially the Centini-conspiracy, ${ }^{90}$ involving an ageing cardinal and his nephew who tried to poison the Pope, gets full coverage, showing that however secret the proceedings of the Inquisition, the major elements were

\footnotetext{
84 Gigli, Diario, o.c., 270.

85 Gigli, Diario, o.c., 244/246.

86 Gigli, Diario, o.c., 23I.

87 Gigli, Diario, o.c., 270/271.

88 E.g. Gigli, Diario, o.c., 212/2 13.

89 Gigli, Diario, o.c., I92; I98; 249; 250.

90 Cfr. also chapter VIII of this book.
} 
made fully known to a wider public ${ }^{91}$ perhaps precisely because the authorities hoped they might serve as a warning. Of course, people did well to heed such warnings, for everything connected with public speculations about the Pope's death was treated with the utmost severity. When the secretary of the papal nuncio to Spain was found to have betrayed his master's secret instructions to the Spaniards, this, in itself, was a serious crime. But the fact that he also predicted the reigning Pope's imminent demise got him the death penalty: he was beheaded. If he had not been a priest, he would have been quartered alive. ${ }^{92}$

Both an acute awareness and, also, some almost overt criticism of the personal power not of the Pope but of the system which he symbolised is voiced when Gigli describes how, in I640, the Camera Apostolica allows the reduction of the interest rates on the loans contracted by private persons and public entities alike. Obviously, the first to profit from this decision was the papacy itself, which had incurred huge debts precisely during Urban's pontificate. Those who had subscribed these loans, including a great number of pious foundations, lost part of their income and, even worse, part of their capital as well, Gigli explains. ${ }^{93}$ However, when the Pope orders extensive and expensive fortifications to be constructed on the Gianicolo Hill, Gigli is more than usually positive in his praise, for this creates jobs for thousands of Romans. $\mathrm{He}$ is equally positive about the Pope's decision to lift the obligation to attend mass on a number of religious feasts, obviously to allow the Roman artisans to use these days to do some productive work; he does note, however, that many simply continue to treat these days as free ones..$^{94}$

This last example indicates Gigli was fully conscious of the power of the Pope's arm spiritual as well. Perhaps it was made most visible when it was wielded in the processes against heretics of all sorts that occurred every now and then though certainly not as often as igthcentury historiography has made people think. In Gigli's view, heresy did, of course, exist. Marc'Antonio de'Dominis, mentioned already, was a prelate of Lutheran leanings, who had proclaimed himself pope in England and had created no less than 34 cardinals. He was brought

\footnotetext{
91 Gigli, Diario, o.c., 266/ 268.

92 Gigli, Diario, o.c., 333.

93 Gigli, Diario, o.c., 335.

94 Gigli, Diario, o.c., 374; 388; 373/374.
} 
to Rome, put in prison and, finally, died after having renounced his heresies. Now, however, it was discovered that even while serving time in the Inquisition's prison he had continued corresponding with the English government. Therefore, his body was exhumed and publicly burned on Campo de'Fiori, together with his likeness.

Another heretic, who, though a priest, had felt free to say mass as many times a day as he liked, was burned alive. ${ }^{95}$ Also, public punishment was meted out to priests who had sinned against their office by indulging in carnal relations; they usually were imprisoned first and then sent to the galleys. ${ }^{96}$

In i634, Gigli became vividly aware of the Pope's spiritual power once more, as Urban decreed that all those who held a bishopric should take their leave from Rome and take up residence in their see as was, of course, what Canon Law demanded. Grumbling because the timing could not have been worse - it rained heavily and soon it started snowing, too - the prelates prepared themselves for departure and, though many procrastinated, finally left. According to Gigli, they never forgave the Pope, a fact which, or so he wrote, did explain why, after Urban's death, his Barberini relatives, fearing revenge, hastily fled the City. ${ }^{97}$

Among the main instruments of the papal arm spiritual were the jubilees that conceded all kinds of graces to the faithful, though, as Gigli clearly realized, these had a rather obvious material side as well. When, in December i624, Pope Urban opened the Holy Door to commence the celebrations of the next Holy Year, I625, Gigli was quick to note that, the amount of pilgrims being far less than expected because of the wars in northern Italy, the Pope cleverly suspended the declaration of indulgences outside Rome, thus using his spiritual power to lure the faithful to the Eternal City after all..$^{98} \mathrm{He}$ was aware that Urban wielded this weapon quite often, as with the universal jubilee which he declared in April, I628, to create a context for two weeks of prayer for peace among the Christian princes: it did indeed cause many pilgrims to come to St Peter's. ${ }^{99}$ The occasion was repeated in 1629 and subsequent years. ${ }^{100}$

\footnotetext{
95 Gigli, Diario, o.c., 58; 139.

96 E.g. for a number of different crimes Gigli, Diario, o.c., 330.

97 Gigli, Diario, o.c., 255.

98 Gigli, Diario, o.c., I39/I40.

99 Gigli, Diario, o.c., I72/I 73 .

100 Gigli, Diario, o.c., I76 and passim.
} 
All the while, Gigli was particularly aware of the Pope's power to change the time-hallowed order of things, as when Urban, to implore God's blessing for his pontificate, declared yet another a jubilee; instead of asking people to attend the traditional churches where, after confession and communion, they could obtain an indulgence, he ordered that in each city-ward two churches would have that privilege; also, he freed people of their obligation to fast and to give alms before an indulgence could be granted. ${ }^{101}$ Once again when, in I629, Urban forbids the traditional procession, on the night of Maundy Thursday, of the town's innumerable confraternities to St Peter's, there to be shown the 'Sacred Face', the 'Veronica', and the Sacred Lance, of St Longinus, because these candle-lit cavalcades are increasingly used by lay people and clergy alike to show themselves rather than to add to the devotional spirit of things, Gigli completely agrees: he feels that the potential of such processions should concentrate on the essence, for example through the impact of those who flagellate themselves and through the cartoons depicting the mysteries associated with the various patron saints of these religious companies. ${ }^{102}$ Yet another occasion occurs when, due to the perils of the plague, the three basilicas that are without the walls cannot be reached: the Pope confers their spiritual properties on three otherwise not so privileged churches within the town's precincts. ${ }^{103}$

Often, though, Gigli was rather ambivalent when confronted with such manifestations of papal power. On the one hand, something definitely like pride rings through when he tells of the power the Pope has in declaring such a jubilee for the entire Christian world. ${ }^{104}$ But when, in the 1640 s, the number of jubilees increases, while the political situation gets worse and, indeed, the need for prayer is greater than ever, Gigli also notes that the Pope, or his relatives, use the occasion to very materially raise taxes in the wake of such concessions of spiritual grace. ${ }^{105}$

Regarding other visualizations of papal power, Gigli, being the proper Roman he was, held mixed views, too. Thus, when a church was

\footnotetext{
101 Gigli, Diario, o.c., I33.

102 Gigli, Diario, o.c., I77.

103 Gigli, Diario, o.c., in I625: I44; again in I630: I9I.

104 Gigli, Diario, o.c., I8I.

105 Gigli, Diario, o.c., 425.
} 
dedicated to Pope Urban I, the Saint who had baptized St. Cecilia, outside the Porta Appia, to commemorate, also, the reigning pope, he gives the news a few non-committal lines, only. ${ }^{106}$ The tale of the discovery of an egg produced by a cock belonging to an old woman, which showed a sun, and, over the sun, a bee, while under it the letters $\mathrm{C}$ and B could be read - Gigli does not explain them but presumably they were thought to stand for Christ, or for the Church, and for Barberini? - is told without much comment, either, though he does add that Cardinal Antonio Barberini gave the woman io scudi, and that the Pope 'took it as a prodigious occurrence. ${ }^{107}$ But when, in i640, the town council was forced, or forced itself to accept that a statue of the Pope be placed on the Campidoglio, the proud, but really empty seat of Rome's former civic independence, Gigli approvingly recounts how, significantly, Bernini's likeness of Pope Urban is moved there by night and put in its place without 'any sign of public joy.' ${ }^{108}$

For Gigli was morbidly sensitive when it came to the relationship between papal and town government. He gives a glimpse of the power structures underlying Roman society when he describes the funeral of Carlo Barberini, first prince of Palestrina, the Pope's non-cardinal brother. It is paid for by the town, because the two conservators of that year both are indebted to the Pope and his family, the one because a brother of his was made cardinal and the other because his brother had been given a canonry in the chapter of St Peter's. Gigli implies, somewhat sourly, that, thus, the two officials ensured their re-election for another period, or even longer. ${ }^{109}$

Another occasion when the actual power structure surfaced occurred when the town council decided that an inscription commemorating the Pope's acts should be put up in Sta Maria in Aracoeli, and that the Cardinal-Padrone should be honoured with a statue. Gigli clearly thinks little of this plan which, he writes, was concocted by the two conservators of the day, who wished to enter Urban's and Cardinal Francesco's good graces, they, too, demeaning themselves in order to have their term of office prolonged. Wisely, or so Gigli thinks, Barberini refuses, only consenting that his name be modestly mentioned in the inscrip-

\footnotetext{
106 Gigli, Diario, o.c., 284/285.

107 Gigli, Diario, o.c., 332.

108 Gigli, Diario, o.c., 331/332.

109 Gigli, Diario, o.c., I96.
} 
tion for his papal uncle. ${ }^{110}$ Meanwhile Francesco's brother Taddeo Barberini, who succeeded his father Carlo as second Prince of Palestrina, and was created Prefect of Rome in I63I, came in for serious criticism precisely within the sensitive context of papal-urban relations, especially when he convinced his papal uncle that he should be given such privileges as formerly belonged to the town's conservators. ${ }^{111}$

\section{The power of the papal relatives}

Indeed, Gigli was markedly critical of the papal relatives, who, as a group, during Urban's pontificate are among the persons mentioned most in his diary, indicating the importance of their role in Rome.

At the beginning of the new reign, Gigli seems to have decided to give the new pope's family the benefit of the doubt. When Urban, two months after his election, conferred the red hat on his nephew Francesco, Gigli wrote about the latter as a 'boy of whom much is expected, and who is very worthy of his new dignity'. ${ }^{112}$ Subsequently, although the occasions on which Cardinal Barberini appears on Gigli's stage are not numerous, he always is mentioned with respect.

Thus when, in April I636, a veritable mini-war erupts between the French and the Savoyards on the one hand, and the Spanish on the other, the price Rome paid for having such large foreign communities at a time when all of Europe was at war. With a new "sacco" threatening, Barberini is informed. Not only does he send the town's policemen in full force, to help contain the two groups within the confines of two separate squares, but he also appears in person, which helps to restrain them and prevents the worst, for no deadly casualties occur. ${ }^{113}$

In February 1637, the Tiber overflows once more, this time coming up to the Corso. Cardinal Barberini asks to be punted through the streets that have been inundated, to distribute bread, and Gigli adds that this is 'an act which once more shows him to be, as always, a pious and really good prince.' ${ }^{\prime 14}$ However, Gigli's seeming partiality for the Cardinal may be partly explained by the fact that, in I638 and again

\footnotetext{
110 Gigli, Diario, o.c., 248.

111 Gigli, Diario, o.c., 34I.

112 Gigli, Diario, o.c., I 32.

113 Gigli, Diario, o.c., 283/284.

114 Gigli, Diario, o.c., 292/293.
} 
in I64I, Francesco confirmed his election to the office of prior of the ward-masters, ${ }^{115}$ which, of course, was the climax of Giacinto's career. Indeed, there must have been some special relationship between Gigli and the Cardinal for even in I644, when Gigli's name had not been put in the urn, the Cardinal had him appointed master of the Campitelliward. ${ }^{116}$

Yet, Gigli definitely was less charmed by the other Barberini men. Indeed, he mentions them mostly in a negative context. One of the reasons certainly was that from the late i62os onwards the threat of war caused the Pope to demand ever more and heavier taxes from his capital. At the beginning, the 'People of Rome' flatly refused. Gigli, without giving his personal opinion, does note that many complained there was no need for these taxes in the first place 'because the Pope continually presented gross sums to his brother, and his nephews, who held the post of General of Holy Church, and other military functions, as well as buying them principalities and lordships'. ${ }^{117} \mathrm{He}$ also notes how, as the nephews of the previous popes begin to die, the functions which their uncles had given to them were all redistributed to the reigning pope's religious relatives. ${ }^{118}$ With some glee he notes that, on the imminent extinction of the House of Aldobrandini, the last representative - a girl called Olympia, who had entered a nunnery while worth not only a princedom but also some four million scudi in gold - was snatched before the very eyes of the greedy Barberini and married off to a Borghese boy by his scheming family. ${ }^{119}$

When, in 1639 , the Pope orders a new monastery to be built on Monte Cavallo, near the papal summer palace, to house his two Carmelite nieces who used to live in Florence, Gigli seems faintly displeased. This monastery, subsequently named 'of the Barberini nuns' was, after all, built solely because of Urban's affection for these two girls. ${ }^{120}$

Against this background, not surprisingly it is always the Roman, rather than the papal side Gigli takes when local loyalties are wounded. This occurred, for example, when Prince Colonna wilfully got into

\footnotetext{
115 Gigli, Diario, o.c., 307; 341.

116 Gigli, Diario, o.c., 424 .

117 Gigli, Diario, o.c., I9o.

118 Gigli, Diario, o.c., 225, when Ludovisi died; 236, when Borghese died; 309, when Aldobrandini died, all three former cardinal-nephews.

${ }_{119}$ Gigli, Diario, o.c., 308/309. Cfr. 416/417 for further details.

120 Gigli, Diario, o.c., 319; 325 .
} 
a fight with two young Roman noblemen of the ancient Caetanifamily who were accompanied by a few other local boys. The next day, the imbroglio continues and in consequence one of the Caetani dies. 'The whole of Rome was in an uproar', Gigli writes, and most people, including the Sacred College, the foreign ambassadors and the Roman barons sided with the Caetani ${ }^{121}$ — surely, we are inclined to conclude, because they wanted to embarrass the Barberini, who had related themselves to a 'foreign' family: the Colonna were from Naples.

Gigli's limited partiality for the Barberini family surfaced particularly when Donna Anna Barberini, the wife of the Pope's nephew Taddeo, decided she wanted a piece of the mortal remains of St Philip Neri, the founder of the Oratorians. His was about the only body of a saint still available in its entirety and, moreover, frequently shown to the people of Rome, who felt him to be their particular property. Thus, when the lady, waving a papal permission, asked that she be given her relics, public commotion ensued, and the monks decided to hide St Philip; rumour had it that when they removed him from the casket, the lamp that always burned before it went out all by itself. Ugly words were spoken by the papal officials who came to support Donna Anna's claim, but the Oratorian fathers, not to be accused of disobeying the letter of the Pope's orders, only relinquished the reliquary which held the saint's heart. After some months, the body was returned to its chapel, though, Gigli added - as if to indicate that papal power always would have its way - it did lack some parts ... ${ }^{122}$

In the late i63os, Urban's health declines, and he starts relying increasingly on his relatives to manage the affairs of Church and state. Consequently, the Barberini presence in Rome becomes ever more notable and, almost inevitably, criticised. In the first years of the next decade, when war breaks out, the Pope finally gets disgusted with the way the Cardinal-Padrone handles things and, according to Gigli, a terrible scene occurs during which the Pope, stamping his feet, throws his beret in the face of another high official present. Subsequently, he even forbids Cardinal Francesco to attend the war council. ${ }^{123}$ It soon appeared that the Cardinal, while aware of the fact that his brother Taddeo - who had succeeded his father as general of Holy Church-

\footnotetext{
121 Gigli, Diario, o.c., 25I/253.

122 Gigli, Diario, o.c., 305/306.

123 Gigli, Diario, o.c., $36 \mathrm{I}$.
} 
had completely mismanaged the military side of the war, had yet felt he could not intervene. Now the Pope was rumoured to have said he finally knew what sort of relatives he had: the first one a saint, who, however, did not know how to work a miracle, meaning Francesco; the second one a friar, who, however, knew no patience, meaning Cardinal Antonio, the Elder, the Capuchin; the third an Oratorian who, however, did not now how to talk, meaning Cardinal Antonio, the Younger; and the last one a general who, however, did not know how to handle a sword, meaning Don Taddeo. ${ }^{124}$

With even the Pope critical of his own family, the outside world could easily use the Barberini as an excuse for acting against Urban. Gigli knew this, too. When the league of Italian states that, in I643, attacked the Papal States, told the public it did so to punish the papal nephews who had usurped too much power, Gigli wrote they were deceived by the Devil. For surely they opposed the power of the Pope, Christ's vicar, the head of the Church; indeed, rather than laying siege to Barberini castles, they conquered towns and villages belonging to the Church, and meanwhile even served the Barberini interests, for the various members of the family only grew richer because of the offices they now held as army commanders. ${ }^{125}$

\section{Ceremony and ritual: ephemeral power?}

Surprisingly, it is not the changes in the urban texture, expressing the need of popes, Church prelates, Roman noblemen and religious institutions to put their permanent mark on his city that Gigli wanted to record. Unmistakably, the larger part of his notes consist of descriptions of power manifestations that, while they might be visible for three or four days, were more likely to be over within three or four hours: the numerous ceremonies that were the visualisation of spiritual and temporal power in the streets of Rome as ever so many individual and collective acts of ritual behaviour.

Almost all major religious ceremonies get at least a passing mention in Gigli's notes: solemn benedictions, public consistories, the creation of new cardinals, their cavalcades when they went to receive the red hat,

124 Gigli, Diario, o.c., 364.

125 Gigli, Diario, o.c., 393. 
processions, et cetera. ${ }^{126}$ Why, quite often, Gigli decided upon a more or less detailed description, is difficult to grasp. Always, however, in such cases his notes contain illuminating details.

Thus he tells that during the annual festivities commemorating the Pope's coronation, the torch is put to two statues: the one, representing Time, is allowed to turn to ashes, but the other, representing Virtue, remains triumphantly intact. ${ }^{127}$ If a procession is particularly splendid, as the one that annually, on the $5^{\text {th }}$ of October, celebrates the victory of Lepanto, Gigli even describes the entire route it takes. He tells of the huge canvas that shows the battle itself and the moralistic paintings depicting the 'happy' and the 'sad' mysteries of the rosary, the ones coloured and the others in "chiaroscuro" as befitted their subject matter, and, finally, the 'glorious' mysteries, in the brightest colours and surrounded by cherubim and seraphim. He describes in great detail the huge chariot carrying a tower-like silver tabernacle with the image of the Madonna of the Rosary, which is greatly revered and has been painted by a saintly friar of the Dominican Order; at the Madonna's feet, a chorus of little boys dressed like angels sings 'most sweetly'these the last of the groups of singers who have walked along, spread over the cavalcade at regular intervals. Moreover, Gigli notes, with apparent approbation, the great number of orphan girls who, on this occasion, are given a dowry to enable them to marry, but for the seven last ones, who wear huge golden crowns 'which seems to indicate that they want to show that they are going to dedicate their virginity to God'. Finally, however, after noting a number of high-placed persons who participate in this ritual, Gigli singles out the Pope's brother and his sister-in-law for special mention. ${ }^{128}$

The longest description of such ceremonies probably is the one of the procession of the so-called "Madonna della Grotta", in August 1635, which, using Gigli's notes, even now one could follow from street corner to street corner, albeit not from triumphal arch to triumphal arch - Cardinal Barberini's being proclaimed the most splendid onefor these, of course, however costly, were definitely pieces of ephemeral architecture. Though it must have been stupendous - on Campo de'Fiori an altar had been erected that was a copy of the baldachin in St. Peter's - it is not clear why Gigli did single it out. Unless, that is, we

\footnotetext{
126 E.g. Gigli, Diario, o.c., I35, I38, I66, I94.

127 Gigli, Diario, o.c., $32 \mathrm{I}$.

128 Gigli, Diario, o.c., I46/I50; other examples: I7ı/ı72.
} 
assume he knew of the Pope's predilection for the Madonna which, actually, was shown on this occasion, too, as for an entire week sermons were held in San Lorenzo in Damaso - the very public 'private' chapel of Cardinal Barberini in his official residence, the Palazzo della Cancellaria - on Urban's favourite theme, the Immaculate Conception. ${ }^{129}$

Gigli obviously delighted in the pomp and circumstance that accompanied the powers of Rome. He seems to have understood their function on the symbolic level while at the same time he rejoiced in the sheer splendour of the many ceremonies that punctuated life in the Urbs. Thus, rather sarcastically but nevertheless in great detail he described the amount of effort and money spent by the newly-arrived ambassador of Spain to, obviously, impress the Pope and even convert him towards the Spanish position in European politics; when the arrogant ambassador, after his audience, yet was heard to remark that the pope he had met was not the obdurate person people had described to his master, all felt the situation was normalised again: ${ }^{130}$ the Spanish had been taught a lesson, and papal power was secure. However, when the Spanish ambassador, about to present, as was his annual obligation, a white jennet in lieu of the fief of Sicily held from the Holy See by the kings of Spain, for unclear reasons refused to do so on the morning of the feast of Sts. Peter and Paul, as ordered by the Pope, and turned up the night before, Urban was adamant. Next morning, the animal, which had been handed over to some papal officials instead, was found dead, probably poisoned - or so people said. ${ }^{131}$ However, Gigli may well have been voicing some mild anti-Spanish feelings, here. He did so again when reporting on the occasion of the birth of an heir to the Spanish throne: the words he used to describe how the Spanish ambassador had ordered eighteen mules to trudge around town laden with silver vessels, before the same mules were used to carry loads of food to the prisons of Rome, seem to show a faintly deprecatory note. ${ }^{132}$

Another time, when the emperor's brother came to visit Rome, and refused to stage a cavalcade because he had not been given permission

\footnotetext{
129 Gigli, Diario, o.c., 272/274.

130 Gigli, Diario, o.c., I46.

131 Gigli, Diario, o.c., I37.

132 Gigli, Diario, o.c., I8o.
} 
to take precedence over the members of the Sacred College, Gigli seems vaguely satisfied that, once more, papal power was vindicated. ${ }^{133}$

Among the most dazzling processions staged during Urban's pontificate surely were the two solemn entries of the new French ambassador, the Duke of Crequi, in June i633, if only because the ambassador's person was literally decked with diamonds, worth, it was said, some 300.000 scudi $^{134}$ - a sum that would have built a major church. But the great round of festivities caused by the election of Ferdinand III of Austria as King of the Romans and, a month later, by his coronation elicited a long description as well. ${ }^{135}$

Perhaps not surprisingly, the festivities that were part of Rome's own civic ritual never came in for criticism. Thus, the annual Carnival joust on Piazza Navona obviously pleased Gigli. The i634-occasion, organized by the Pope's nephew, young Antonio Barberini, was particularly splendid: Gigli describes it in detail, even listing the 22 young noblemen, mostly of old Roman families, whose participation upheld the reputation of the Town. ${ }^{136}$

A significant moment in the public celebration of papal powerthat, in Gigli's somewhat rosy vision, always was meant to be seen as an example or, perhaps, even a result of Rome's power - was the festive annual tournament, the "Pallio", commemorating the I599-conquest of the marquisate of Ferrara by the Papal States. In August I63i, by some feudal law the duchy of Urbino reverted to the Apostolic See. The Pope decided that the Carnival of 1632 would be celebrated not only with the customary "Pallio" for Ferrara, but with a new one for Urbino as well, though, in view of the miserable conditions prevailing all over Italy, festivities were not really in order. ${ }^{137}$

These recurring ceremonies surrounding the power of the 'People of Rome' - studiously upheld, though by now more fictive than realalways elicited Gigli's pride-betraying descriptions. Still he did realize that he very well knew where the actual power lay, for example in telling how, in the annual senator's procession, behind various bodies of armed men who represented the "Soldati del Popolo Romano",

\footnotetext{
133 Gigli, Diario, o.c., I5I.

${ }^{134}$ Gigli, Diario, o.c., 233/235; see also 237; 238, for another entry, this time of the Polish ambassador.

135 Gigli, Diario, o.c., 291/292; 293. Cfr. chapter 4 of this book.

136 Gigli, Diario, o.c., 246/248.

137 Gigli, Diario, o.c., 2 I9.
} 
the senator pro tempore rode 'surrounded by the papal Swiss Guard'. ${ }^{138}$ Moreover, noting the many urban festivities that increasingly stressed the secular power of the Pope and his relatives, Gigli sometimes seems to loose his enthusiasm for all the grandeur, perhaps precisely because in many of these Urban clearly was the embodiment of the very papacy that had usurped the ancient dignities of the 'People of Rome' of whom Gigli was, however minor, a representative.

Thus, it is not clear whether he believed Urban when, on the occasion of the Possesso - the formal acceptance by a new pope of his position as 'King of the Romans' - he declared that he really did not want his people to spend so much money. ${ }^{139}$ Certainly, on subsequent occasions the Pope never seems to have bothered about the cost of civic ceremony. Therefore, Gigli could and did give ample coverage to the sumptuous cavalcades that, in I630, were staged to celebrate Taddeo Barberini's nomination to the venerable office of prefect of Rome, on the death of the hereditary prefect, the last duke of Urbino. ${ }^{140}$ However, he also positively jumped at the opportunity to indicate that many people felt disgusted by the papal decision, and, consequently, failed to show up at the festivities. Indeed, he recounts with evident glee the ceremonial struggles that ensued between the foreign ambassadors, who refused to let the newfangled prefect take precedence. ${ }^{141}$

Gigli again clearly deplores the obvious inroads made by the papal authorities into the former independence of Rome's city council when, in 1634 , the carriage in which the two conservators and the city prior travelled was held up, and the latter imprisoned for debt, a thing unheard of in former times. 'To this end has come the Majesty of the Roman People', he sighs, implying that precisely the admittance to the council of men who are willing to behave like creatures of the papacy is causing the downfall of that millennial institution, the "Senatus PopulusQue Romanus." 142

\footnotetext{
138 Gigli, Diario, o.c., I75.

139 Gigli, Diario, o.c., I33.

140 Gigli, Diario, o.c., 206/208.

141 Gigli, Diario, o.c., 209/2 Iо.

142 Gigli, Diario, o.c., 248.
} 
Holy or unholy power?

Obviously, Gigli believed in the power of the Church, or rather of the Faith. When a six-year old Jewish girl decided to become a Christian and, despite the earnest warnings of the prelates of the 'Congregation of the Catechumenes' that she had better return to her parents, for three years persisted in her wish, he felt she was, indeed, saved. ${ }^{143}$ Likewise, he accepted such an institution as the 'Casa Santa', the House of the Holy Family, at Loreto, as entirely genuine because its transfer to Italy - by angels - was a historical fact that had occurred during the pontificate of Boniface VIII. ${ }^{144}$

Still, in a great many cases Gigli seems to have wondered what, exactly, was part of the divine power of the Church, how to decide whether a manifestation of power emanated from Heaven or Hell, was white or black magic. Did he believe the supernatural forces intervened in Man's life, warning the world with their signs?

In December i634, a fire started that in the end destroyed three shops and threatened the neighbouring houses. At that very time, a procession with the Holy Sacrament passed along the street, and the priest sprinkled the flames with Holy Water, which doused them a little. Soon, it started raining, and further disaster was averted. ${ }^{145}$ Yet, while many did hail this as a miracle, Gigli himself does not seem to have known what to make of it. He also kept an open mind when reporting the story of a woman who, threatened by a burglar, asked for a few minutes to say an Ave Maria in front of an image of the Madonna; while the burglar prepared the rope which he was planning to use to hang her with, the stool on which he stood collapsed and the knife he held severely wounded him, enabling the woman to call for help and have her molester arrested. ${ }^{146}$ In a case of suspected arson, that caused three women to be burned alive, Gigli wrote that the elder one was 'not too honest a female', as if to imply that, somehow, this made the situation less sad than otherwise would have been the case, also because, through God's influence, the younger daughter of this woman escaped: she had asked to be allowed to stay with an aunt. ${ }^{147}$

\footnotetext{
143 Gigli, Diario, o.c., 224.

144 Gigli, Diario, o.c., 299.

145 Gigli, Diario, o.c., 254/255.

146 Gigli, Diario, o.c., 268/269.

147 Gigli, Diario, o.c., I7o.
} 
Yet he does not qualify what had happened: was it retribution and salvation, or sheer chance and luck? In December i636, a person was sentenced to death because he had been accused of being the author of anti-government pamphlets. Marquis Manzolo Bentivoglio did not confess, but two witnesses testified against him, which was enough to have him beheaded. However, before being killed himself, one of the witnesses retracted. It was too late, but people did note that nearly all those somehow connected with the process soon died, too, of unnatural causes. ${ }^{148}$ Again, Gigli does not give his own views of the matter.

Some 'signs', however, Gigli seems to have felt to be unequivocally supernatural. When a flash of lightning entered the Gesù-church and travelled all around it, going out through a side door and passing between the legs of a man just entering, he noted it without any critical comment. ${ }^{149}$ Also when, all through August 1624, the heavens show complex conjunctions of the planets in the signs of Leo and Virgin, which Gigli describes as huge rays, like swords wielded in battle, he does not connect them to any natural force. ${ }^{150}$

Moreover, Gigli may well have believed the heavenly powers could be consulted and their actions foretold. Thus, in confiding to his diary who of the cardinals and other prelates had asked the advice of astrologers, as he often does, he seems to imply they always were given predictions that actually came true. ${ }^{151}$ But when, in i63o, a number of widely influential astrologers and their collaborators who copied their prognostications for distribution were imprisoned, Gigli refrains from comment. ${ }^{152}$ For in this case who was to decide between white or black magic?

Often, however, it was not that difficult. Thus, Gigli unfailingly notes miracles, especially miraculous healings. ${ }^{153}$ Sometimes, he does not bother to describe what actually happened, or was supposed to have happened, nor does he disclose his own views in the matter. ${ }^{154}$ Sometimes, he seems to hesitate between simply accepting what happened, and putting his trust in the words of others. In June I643, a

\footnotetext{
148 Gigli, Diario, o.c., 286.

149 Gigli, Diario, o.c., I92.

150 Gigli, Diario, o.c., I38.

151 Gigli, Diario, o.c., I32.

152 Gigli, Diario, o.c., I95.

153 E.g. Gigli, Diario, o.c., I89 and passim.

154 E.g. Gigli, Diario, o.c., I33, the case of the "Madonna della Riccia".
} 
three-year old girl was brought to Rome who had been born with the sign of the Cross imprinted on her alveolar ridge and, through it, could make any liquid produced by her mouth into a healing substance. Gigli just tells his diary that the girl's father had with him many signed attestations. ${ }^{155}$

Occasionally, Gigli goes out of his way to relate what actually occurred. Once, a poor boy started receiving visions of the Virgin and, though he was told to attend to his job, continued to return to the place where She had appeared to him first, the gate to a vineyard in Trastevere. Soon, word got around, and many people congregated there, and were being miraculously healed of all kinds of infirmities and even liberated of the Devil. After a few days, the vision of the Madonna, which now somehow had materialized, was transferred to the basilica of Sta Maria in Trastevere and even given a special altar, there, where yet greater multitudes came to view and revere the picture. ${ }^{156}$

Another time, during the procession of the Madonna of the Rosary, in October 1625 , a heavy cart ran down a monk who normally would have died of his wounds. However - Gigli writes: 'I cannot pass in silence over a manifest miracle' - when the cart had passed, the monk, who had recommended his soul to the Madonna, arose and, after three days in bed, went about his business as usual. ${ }^{157}$ Indeed, the Madonna held great power over the Romans, not least over Gigli himself. After her image miraculously appeared in fresco on a wall in a vineyard outside Porta del Popolo, he delves into the story as well, though he precedes his tale with a 'people say that it went as follows'. The image was consequently transferred to the monastery adjacent to the church of Sta Maria del Popolo. ${ }^{158}$

Nevertheless, the Roman authorities were not always keen on having these miracles do their work. When, in 1633 , yet another image of the Madonna began attracting numerous people because of its supposed miraculous properties, the Pope's representative had the church closed. ${ }^{159} \mathrm{Also}$, the religious establishment seems to have been quite circumspect in qualifying as miracles the numerous other cases people were eager to so interpret.

\footnotetext{
155 Gigli, Diario, o.c., 394.

156 Gigli, Diario, o.c., I35/I37.

157 Gigli, Diario, o.c., I50.

158 Gigli, Diario, o.c., I67/168.

159 Gigli, Diario, o.c., 236.
} 
Thus, in I637, a nun, who had not professed yet, because she had fallen ill and, for years, could not move a single limb, started having visions of the Virgin who told her she would be healed if only she founded a new monastery devoted to the constant contemplation of Christ suffering at the Cross. To be convinced of her mission's blessing, the nun simply should enter her monastery's church and ask for her non-functioning limbs to be rubbed with the sacred oil. After some arguing, the woman was indeed allowed to do so and, lo and behold, her legs and one of her arms regained their function but for the other arm that, according to the Virgin, she would have to use to don the habit of the new community she was to found. At that point of the story, Gigli went on to give a, for him, unique comment: 'The Order's superiors have instigated an enquiry, and found the miracle to be true. But as to the visions it is difficult to certify they are indeed given by God; such visions cannot be said to be true if the Apostolic See has not approved them'. ${ }^{160}$

In short, the power to verify and hence legitimate the manifestations of the supernatural is, indeed, the Pope's, as the embodiment of the Church. When a son of the king of Poland visits Rome, the Pope makes him a canon of St Peter's. This honour, writes Gigli, gives the Polish prince the right to take the Sudarium, the sweat cloth of St. Veronica with Jesus' face imprinted on it, in his hands and show it to the people. Obviously, Gigli felt that this action represented the manipulation of the sacred, of holiness - both on the Pope's part, who could bestow this gift to a mere mortal, and, subsequently, on the part of this man himself. ${ }^{161}$

Indeed, Gigli often seems to have reasoned that the involvement of the Pope or his near relatives in such cases served as proof that everything was above doubt, as in the case of the Capuchin monk who had died at the venerable age of 94 years, and whose corpse then was said to be the cause of many miracles; ${ }^{162}$ a few years later, in I631, Urban and his Capuchin brother Antonio having completed the building of the church of the Immaculate Conception on the present Via Veneto, ${ }^{163}$ the bones of this Fra Francesco were among the many thousands that, in three hundred cartloads, were solemnly transferred to this new seat of the Capuchin Order. In another case, in I634,

\footnotetext{
160 Gigli, Diario, o.c., 289/29o.

161 Gigli, Diario, o.c., I39.

162 Gigli, Diario, o.c., I59.

163 Gigli, Diario, o.c., I59/ı6o; 206.
} 
the remains of a second-century martyr, Saint Martina, and two other blood witnesses were discovered under the altar of the church dedicated to her. Saint Martina's head was fully intact and, what was more, her heart, still 'sanguineous and tender', was preserved in a glass vase filled with white fat. Many people came to venerate the relics, including Pope Urban himself with a suite of twelve cardinals. ${ }^{164} \mathrm{~A}$ few months later, the bodies were re-interred in their original place, and Cardinal Barberini decided to rebuild the entire church. ${ }^{165}$

The discovery of the body of Saint Francesca Romana, in April s638, also brought about miracles: when the Pope's representative put the Saint's arm between the arms of a nun who had been unable to use her own for many years because her nerves had been cut in an accident, she immediately opened her hands. Also, a blind man regained his vision, people possessed by the Devil were liberated from evil spirits and many sick persons were healed. ${ }^{166}$ The following day, the same nun, now being touched with the Saint's legs, was able to walk about church to the utter stupefaction of all present. Many other miracles subsequently occurred.

Once again when, in I639, a Franciscan monk died aged Io6, of which he had spent go years in his monastery, he was immediately reputed to be a saint. His corpse was shown to the public, who arrived in great numbers to venerate him. Not only did it work many miracles, also, rigor mortis did not set in and when the papal physician arrived to experiment on it, it continued to bleed as if still alive. Even after the monk's body finally had been interred, his tomb was repeatedly opened and, always, his body gave off the smell of violets. Many people were freed of demons when brought to his grave. ${ }^{167}$

\section{The ageing of power}

From I64I, onwards, Gigli must have felt that a long period was, slowly, drawing to a close. Ever more often he noted the Pope was unable to attend the functions at which he normally was present. ${ }^{168}$ Yet he himself

\footnotetext{
164 Gigli, Diario, o.c., 254.

165 Gigli, Diario, o.c., 265 .

166 Gigli, Diario, o.c., 309/3 10.

167 Gigli, Diario, o.c., 322.

168 Gigli, Diario, o.c., 339/340: February, ı64I; March I64I; April ı64I; May i64ı.
} 
probably had his first audience ever with Urban precisely in these years. For in September I64I, the 'People of Rome' decided to offer the Pope, as of their own will, to pay for 3000 soldiers in case the imminent war over the duchy of Castro with Odoardo Farnese, duke of Parma, finally broke out. With (the risk of) hindsight, Gigli's description of the moving scene during which the senior conservator pledged the People's support to the Pope seems a first-class piece of satire. The Pope is reduced to tears and commands the kneeling town representatives to rise while he harangues them on the need to punish a disobedient vassal of the Church. ${ }^{169}$

Soon afterwards, Urban created the huge number of thirteen cardinals, ${ }^{170}$ to fill the vacancies that had been falling during the previous years. Obviously, he needed to restore the Sacred College to its full capacity of 70 members, if only because cardinals were needed to head the various offices of Church and state. Also, he must have felt he might need the support of as big a group as possible now that war had, indeed, begun. Finally, he may have sensed that his end was near and that the number of electors should be brought up to par, if only, perhaps, to ensure, through selecting his own men, the continuation of his policies.

Meanwhile, the very fact that papal government had to cope with the war against Parma, coupled, one must assume, to the fact that the Pope himself was less able to control things, made life in Rome decidedly more dangerous. Tales about soldiers ready to kill at any moment, and a group of "Borgognoni", Spanish subjects rumoured to have complotted to set fire to all the hay lofts in town, to be able to sack it in the ensuing panic, now dominate the diary. ${ }^{171}$ In this climate, Gigli was inclined to believe the earlier predictions of a Franciscan monk, Bartholomeo da Saluthio, that bode ill for Rome's future, the more so since the monk had argued that things would to turn for the bad when men and women would start dressing in the same manner. That was precisely what Gigli noticed wherever he turned, now: 'God deliver us from all evil', he sighed. ${ }^{172}$ In September i642, people really start panicking, many deciding to leave Rome, among them a considerable

\footnotetext{
169 Gigli, Diario, o.c., 342/343.

170 Gigli, Diario, o.c., 345.

171 Gigli, Diario, o.c., 352/356.

172 Gigli, Diario, o.c., 357.
} 
number of nuns ${ }^{173}$ who, apparently, feel they will be among the first to suffer at the hands of the brutes that soldiers are. Inevitably, there is a run on the banks, and people start hiding their valuables. ${ }^{174}$

Meanwhile, the Duke of Parma's armies are marching on Rome, and the papal troops do not give them battle because the Pope is supposed to have ordered that no blood shall flow. ${ }^{175}$ But then the Parmesan army sidesteps into Tuscany. Gigli gives no reason, but obviously it's because winter has set in. With a sigh of relief, Rome realizes it has, for the time being at least, escaped almost certain destruction. Those papal soldiers who have families are allowed to return home, to help sow the fields. ${ }^{176}$

But in spring 1643 , the campaign starts again, ${ }^{177}$ and, worse, the Tuscans and the Venetians now join Parma, seeing their chance to have past wrongs, real or imagined, revenged. Also, the troops quartered in Rome get more unwieldy every day. ${ }^{178}$ An avalanche of edicts aggravates the lives of the Roman people. Thus, they have to turn in all their silverwork, and are given government bonds in recompense-nearly worthless pieces of paper, Gigli implies. ${ }^{179}$ Criticism of government policy is increasingly openly voiced, fomented also by the Florentine community in Rome, who are outraged because the Pope has excommunicated their city for joining the league against him. ${ }^{180}$ People grumble the more as taxes are raised almost every day, with the so-called approval of the People of Rome, though in reality everything is ordered from the Vatican, Gigli rather bitterly notes. ${ }^{181}$

From the beginning of the year I644, everyone in Rome knew the Pope, now aged 77 , to be dying, and the conservators already decided to close the hall on the Campidoglio where Urban's statue had been placed, for fear of future troubles. ${ }^{182}$ Though in May a peace treaty was finally signed, ${ }^{183}$ yet new taxes were being introduced all the time, with everybody realizing that it was the Barberini family, and, more

173 Gigli, Diario, o.c., 362.

174 Gigli, Diario, o.c., 369; 363 .

175 Gigli, Diario, o.c., 370.

176 Gigli, Diario, o.c., 370/371.

177 Gigli, Diario, o.c., 388.

178 Gigli, Diario, o.c., 39ז.

179 Gigli, Diario, o.c., 392, 398.

180 Gigli, Diario, o.c., 397; 4II.

181 Gigli, Diario, o.c., 399; 40I/402.

182 Gigli, Diario, o.c., 411/413.

183 Gigli, Diario, o.c., 417. 
specifically, Cardinal Francesco who now ordered them. Consequently, the Cardinal-Padrone was jeered at whenever he went about town. ${ }^{184}$

On the 28th of July, Pope Urban VIII finally died. The Romans were both overjoyed, and enraged. As the gentlemen of the City Council had feared, they could barely prevent the populace from venting their fury on the Pope's statue. When the papal body was exposed in St Peter's, it was said to give off an evil smell. Yet numerous people came to see it, and terrible scenes ensued, with a number of persons being killed. ${ }^{185}$

When Gigli sat down to evaluate Urban's 'performance' as a pope, he judged his first fourteen or fifteen years to have been very good ones indeed, noting that if this learned man, this patron of the arts had died at that time, he would have been counted among the best popes, ever. However, during the second period, when he had been increasingly ill, he had left power in the hands of his nephews. Already, they had amassed incredible riches and now continued to do so, burdening the people with a multitude of taxes, and allowing relations with foreign powers to deteriorate. ${ }^{186}$ Thus, what later turned out to be the longest pontificate of the I7th century ended on a sad note.

Yet, on more mature reflection, Gigli felt that the more extreme antiBarberini manifestations were, perhaps, a trifle unjust and uncalled for, the more so as they originated with men who had every reason to be grateful to the deceased pope and, indeed, to his family, who now fled the town. ${ }^{187}$

Meanwhile, a long, eventful conclave had followed, full of haggling and intrigue. When a new pope finally was elected, Gigli noted that the people of Rome were little satisfied, as Cardinal Benedetto Pamfilj was known for a severe man who, also, 'was not very open-handed.'188 In view of the judgement passed on the spendthrift Barberini, one may wonder whether Gigli was being ironic.

${ }^{184}$ Gigli, Diario, o.c., 424

185 Gigli, Diario, o.c., 426/427.

186 Gigli, Diario, o.c., 425.

187 Gigli, Diario, o.c., 429.

188 Gigli, Diario, o.c., 43I. 


\section{Conclusion}

Giacinto Gigli provides a sound antidote to a vision of Rome that is, obviously, one-sided, created as much by the romantic, ruin-filled images of the town of the late I8th and early igth century as by the many scholarly studies that have been written since the early 2oth century, and that concentrated, mostly, on high art and high politics. ${ }^{199}$ Judged on the basis of his diary, Gigli seems to have cared little for all those materializations of high culture that we have come to associate with Baroque Rome. The great feats of the arts, of science and of scholarship, whether they be the works of Pietro da Cortona, Galileo Galilei or Athanasius Kircher failed to catch his attention. Indeed, the only references to these fields of culture concern music, which Gigli often mentions though, as was usual at that time, he mostly fails to note the composer's name. ${ }^{190}$

Though it is difficult not to read too much into a text that, albeit a private one, shows less emotions than we might nowadays expect, it seems safe to say that what Gigli was interested in most was, indeed, power, in all its manifestations. Quantitatively speaking, more than a third of his entire diary is made up of notes precisely describing the most visual expressions of power: the sumptuous religious processions celebrating the ideas of the Church, the complex cavalcades representing the views of temporal government, and, perhaps surprisingly, the actions and the final, highly 'visual' undoing of those who claimed a power that, though it was 'unauthorised', i.e. not held by either temporal or spiritual authorities, yet were thought to be able to wield it effectively: the prognostications and the public executions of astrologers, conjurers, necromancers and their like.

Rather than ascribing the power behind all these manifestations and expressed in them to the person of an individual pope, or his relatives, or to the representatives of the various European princes, the members of the religious Orders or even to those men and women who claimed contact with the supernatural, Gigli seems to have admired and respected power as part of the essence of life in his town. It was Rome itself, where daily ritual helped to keep that power intact, that

\footnotetext{
189 Cfr. Rietbergen, De retoriek, o.c., passim.

190 Barberito, in his introduction to Gigli, Diario., o.c., lvii writes that Gigli does not write a single line about music, which makes one wonder about the way he has read the diary.
} 
perhaps constituted the fundament of Gigli's 'worldview'. But at the same time, the power of the pope, the ruler both of Rome and of the entire Church, was an essential part of the power of the town, for it was to him that all the world came, kissing his feet in reverence for and acceptance of that power. 